\title{
Dramatis Personae in the Acts of Peter: Character Identification and the Conveyance of Ethical Values
}

\author{
Thomas J. Kraus \\ Department of Theology, University of Zürich, Zürich, Switzerland \\ thomasj.kraus@uzh.ch
}

\begin{abstract}
The Roman senator Marcellus plays a prominent role among the considerable number of characters mentioned in the apocryphal Acts of Peter. He was very important for the Christian community, and his house was a central meeting place for widows, orphans, foreigners, and the poor, before it became the residence of Simon Magus and his followers. By applying a specific approach of cognitive narratology and by taking serious an active participation of readers in analyzing a character more closely, this study intends to analyze the extent to which such an approach might help to perceive and understand Marcellus more appropriately and to highlight his function within the story and his impact on readers.
\end{abstract}

\section{Keywords}

Marcellus - Simon Magus - Peter - boundary crossing - cognitive narratology - characterization

\section{The Acts of Peter (Acta Petri) - A Story of Conflict and Martyrdom}

The Acts of Peter (ActPet) is one representative of a literary and narrative genre of stories about and with the apostles of Jesus after his death (and resurrection). ${ }^{1}$ The text under discussion ${ }^{2}$ on the following pages is often plainly seen

\footnotetext{
1 Of course, this genre should be defined more closely elsewhere but not here.

2 The extant version of ActPet underlying the following analysis is the parchment codex Bibl. Capitol. 158 of the Biblioteca Capitolare in Vercelli, Italy, which is dated to the 7 th century.is
} 
as just one of the five major apocryphal acts of the apostles (AAA), i.e., the Acts of Andrew, John, Paul, Peter, and Thomas, falsely attributed to Leucinus Charinus as their author, who was accused of having been a gnostic heretic. Consequently, this, among other reasons, led to a sort of disqualification of the apocryphal acts that somewhat remains to this day. ${ }^{3}$

Nonetheless, ActPet has played a special role among the early narratives about the apostles: the talking dog, Simon Magus's flight, Peter's encounter with the resurrected Christ outside the gates of Rome, the so-called Quo vadis scene, and Peter at the cross suspended upside down have become popular topics beyond a merely academic context and have had their effect on readers, authors, and artists alike. ${ }^{4}$ All in all, the narrative itself is rather uniform, though it can be divided into two main sections, just as it is expressed by one of its translators. John F. Stoops, Jr., states: ${ }^{5}$

called Actus Vercellenses. It offers a rather coherent transmission of the Latin ActPet, which was originally composed in Greek (see the parchment fragment P.Oxy. VI 849 from the fourth century and the younger Greek codices $\mathrm{P}, \mathrm{A}$, and $\mathrm{O}$ ). As they do not contain information on Marcellus neither the Acts of Peter in Coptic (вG 8502.4), nor any other potential witness to ActPet that are unrelated to the narrative of Actus Vercellenses are taken into account here. The original text of ActPet is dated to around the year 200 or to "the late second or early third century" and generally located in Asia Minor or Syria. But also more precise attempts to locate its place of composition were made in the course of which Bithynia, Alexandria, Northern Italy, and Rome were suggested as places of origin. Cf. the critical edition of Actus Vercellenses by M. Döhler, Acta Petri: Text, Übersetzung und Kommentar zu den Actus Vercellenses (TU 171; Berlin and Boston: De Gruyter, 2018), especially pp. 43-48 (history of research, date, and place of origin). Further see the discussions in M.C. Baldwin, Whose Acts of Peter? Text and Historical Context of the Actus Vercellenses (wUNT 2/196; Tübingen: Mohr Siebeck, 2005), pp. 302-303; O. Zwierlein, Petrus in Rom: Die literarischen Zeugnisse. Mit einer kritischen Edition der Martyrien des Petrus und Paulus auf neuer handschriftlicher Grundlage (UaLG 96; Berlin and New York: De Gruyter, 2nd edn 2010 [2009]), pp. 41-42, and idem, Petrus und Paulus in Jerusalem und Rom: Vom Neuen Testament zu den apokryphen Apostelakten (UaLG 109; Berlin and Boston: De Gruyter, 2013), p. 78.

3 For a brief survey on these and related issues see H.-J. Klauck, The Apocryphal Acts of the Apostles: An Introduction (Waco: Baylor, 2008), especially pp. 1-14; R.F. Stoops, Jr., The Acts of Peter (Early Christian Apocrypha 4; Salem: Polebridge Press, 2012), pp. 36-37; T.J. Kraus, "Vergegenwärtigende Erinnerung - was die Petrusakten (ActPetr) überhaupt über 'Petrus in Rom' erkennen lassen," in J. Frey and M. Wallraff (eds.), Petrusliteratur und Petrusarchäologie: Römische Begegnungen (Rom und Protestantismus. Schriften des Melanchthon-Zentrums in Rom 4; Tübingen: Mohr Siebeck, 2020), pp. 125-157, especially pp. 125-128.

4 Cf. B. Lang, Die Taten des Petrus (Kleine Bibliothek der antiken jüdischen und christlichen Literatur; Göttingen: Vandehoeck \& Ruprecht, 2015), pp. 22-23.

5 Stoops, The Acts of Peter, p. 1. Further see Lang, Die Taten des Petrus, p. 7 (my translation into English): "In den Taten des Petrus werden zwei miteinander verwobene Geschichten erzählt: die Auseinandersetzung zwischen Petrus und seinem Gegner, Simon dem Magier, und der Tod des Petrus. Wir wollen sie kurz als Simonerzählung und Petruserzählung voneinander 
The Acts of Peter is a Christian entry in the second-century marketplace of competing religious claims. The surviving portions deal primarily with the conflict between the apostle Peter and Simon Magus in Rome and the apostle's martyrdom.

The twofold nature of ActPet with the intense conflict between Peter and Simon Magus on the one hand and Peter's martyrdom (and his preaching) on the other has obviously been popular throughout the centuries. Just think of the afterlife and reception of the Simon Magus controversy, the Quo vadis scene, or Peter dying on an inverted cross. ${ }^{6}$ As can be seen from this reception history, characters often remain recognizable by a few traits only. ${ }^{7}$

While the reception history of the ActPet is an interesting topic on its own, my focus is rather on the narrative in its historical context or readers and their appreciation of a certain character. ${ }^{8}$ First, I want to analyze a particular character in more detail, paying attention not only to the traits that are explicitly conveyed, but also to those that readers must infer indirectly. In doing so, I will also trace the development of this character over the course of the narrative. My choice for this purpose is Marcellus, a Roman senator and influential Christian authority of the community in Rome, and one of the main characters in ActPet. But why Marcellus? Marcellus is numbered among the three central characters of ActPet (together with Peter and Simon Magus). It is not just a matter of chance that a later Latin version combining the martyrdoms of Peter and Paul was ascribed to a certain Marcellus, then called Pseudo-Marcellus. ${ }^{9}$

unterscheiden." (The deeds of Peter narrate two interwoven stories: the conflict between Peter and his opponent, Simon the Magician, and Peter's death. Let us briefly distinguish them from one another as the narration about Simon and the narration about Peter.)

6 Cf. the monumental historical movie Quo Vadis (directed by Mervyn LeRoy and brought to the cinema in 1951 by Metro-Goldwyn-Mayer), an adaption of the novel with the same title by Henryk Sienkiewicz from 1896, which promoted knowledge of Peter's encounter with the risen Christ and his crucifixion upside down as depicted in ActPet. In modern popular culture the inverted cross is often used to indicate a reversal, mockery, or rejection of Christian values. For instance, black metal bands use the inverted cross as a recurring iconographic motif.

7 The reduction of character traits to a few specific ones throughout reception history would be a worthwhile study on its own.

8 For a reader-oriented theory of "characterization," see J.A. Darr, "Narrator as Character: Mapping a Reader-Oriented Approach to Narration in Luke-Acts," Semeia 63 (1993), pp. 436o. Also see F.W. Burnett, "Characterization and Reader Construction of Characters in the Gospels," Semeia 63 (1993), pp. 3-28.

9 See H.W. Tajra, The Martyrdom of St. Paul: Historical and Judicial Context, Tradition and Legends (WUNT 2/67; Tübingen: Mohr Siebeck, 1994 [republ.: Eugene: Wipf \& Stock, 2010]), pp. 143-150; D.L. Eastman, The Ancient Martyrdom Accounts of Peter and Paul (wGRW 39; 
From a cognitive science perspective, this becomes easily understandable when considering that Marcellus is the character already present in Rome at Peter's arrival (ch. 8) and even at Peter's death and burial (ch. 40). In addition, Marcellus is a Roman authority, a political representative belonging to the upper class who finally acts in favor of Peter and the Christians in Rome. Thus, as Peter's constant companion and eyewitness, he is ideally suited to vouch for what is being told. Second, I raise the question as to what degree the reader of ActPet is supposed to identify with the "character" of Marcellus and what effect this possible identification might have.

\section{Place Names and Dramatis Personae in ActPet}

The narrative space and individual places often play a decisive role for the characterization of "figures." For example, the setting sets a limit to a character's actions, or rather enables a "character" to do something. Elsewhere I have dealt with the names of people and the names of place in ActPet in some detail. ${ }^{10}$ Although the focus is put on the "character" and "characterization" of Marcellus, the Roman senator, in ActPet in the following, a brief overview of place names and some tentative conclusions might help provide some idea of the localization of the narrative. Moreover, characters are connected to "space" (in ActPet also defined by place names), as Jurij M. Lotman has explicitly pointed out. ${ }^{11}$ Lotman focusses on the spatial organization of texts and, thus, on narrative space and borders that mark the boundaries between spaces. Accordingly, characters in ActPet are linked to places and space (cf. the main characters: Paul in Rome, Peter in Jerusalem, and Simon Magus in Aricia). The narrative offers a clear distinction between "urban" (Rome) and "rural" (Aricia), "inside" and "outside" (e.g., Marcellus's house), "lower class" and "upper class" (e.g., the people coming to Marcellus's house and Marcellus himself), "magician" and "senator," just to mention a few examples. Further, there are certain transgressions of the borders between spaces, for instance, when Paul leaves Rome and Simon Magus threatens to fly into town, when Peter leaves Jerusalem and sails to Rome, when the magician and his followers occupy Marcellus's house and

Atlanta: Society of Biblical Literature, 2015), pp. 221-269, especially p. 224. Although the author of that version of a Latin martyrdom is unknown, "[...] there is a brief notation at the end of some of the Latin manuscripts: 'I, Marcellus, have written what I saw."'

10 Kraus, "Vergegenwärtigende Erinnerung," pp. 125-157.

11 Cf. J.M. Lotman, Die Struktur literarischer Texte (trans. R.-D. Keil; Munich: Wilhelm Fink, 4th edn 1993), 311-347. On Lotman's conception of "space," see M. Martínez and M. Scheffel, Einführung in die Erzähltheorie (Munich: Beck, 11th edn 2019), pp. 16o-165. 
Peter and his companions have to wait outside, and when Peter moves through Rome. Marcellus may even be seen as a transgressor of social and spatial borders (see below). It is important to highlight that narrative space (connected to characters) seems to offer readers orientation within a narrative. ${ }^{12}$

\section{Place Names}

At a first glance geographical information (i.e., everything that could entail the question "Where [exactly] ...?") in ActPet remains general and not compulsory for following and understanding the storyline. Paul is sent to Spain (ch. 6) and therefore must leave Rome. Judea is quoted three times rather en passant (chs. 6, 17, 23) as is Neapolis/Nablus (ch. 17). Jerusalem, Caesarea, the Adriatic Sea, and the port of Puteoli (ch. 5) serve the purpose of tracing Peter's route to Rome, just as Portus, the port of Ostia, and the Tiber do for Paul's route to his departure and that of the crowd accompanying him back to Rome (ch. 3). Aricia, an inland town on the Appian Way, is only mentioned as the residence of Simon Magus (chs. 4 and 32). Both Peter and Magus leave their base and move to Rome; and then a first but crucial encounter takes place at Marcellus's house, a place that has already been described as a major meeting point and haven for people in need. Additional geographical data and other location data at best function in service of answering the reader's question ("Where?"), are matters of common knowledge, and are not elaborated and enhanced in greater detail. ${ }^{13}$ The indication of the city name runs through the narrative of both parts of ActPet, i.e., the deeds of Peter (or Peter's contest with Simon Magus) and his martyrdom (chs. 1, 3, 4, 5, 7, 9, 15, 23, 28, 29, 32, 33, 35); and that the crucifixion of Peter, including his speech and his death (chs. 36-40), is implicitly connected with Rome is obvious. Consequently, the connection of the narrative to Rome as the main location of the plot seems to be of primary importance, while details and specifics are largely missing.

In sum, the narrative space is rather simply structured, though the many mentions of the location "Rome" and the placing of characters there, above all,

12 This is what a cognitive linguistic approach could add to Lotman because it takes the active role of readers serious for reception, interpretation, and analysis.

13 Judea, Caesarea, and Jerusalem may be seen here rather as a connection to tradition and the origin of Simon Peter and Paul which may have motivated their naming. However, this geographical data primarily serves the narrative design of the story itself and satisfies the expectations and the previous knowledge of readers. 
Marcellus, is conspicuous. ${ }^{14}$ Besides, places, names, and information on the locations of the scenes of the plot serve the purpose of establishing a realistic scenario and setting; such local color certainly determines the "characters" and vice versa. In the case of Marcellus, his varied connections to Rome as a resident, a senator, and a member of a community, and his house as the place of conflict and a demonstration of the power of the real God (see the exorcism in chapter 11) serve as clear examples of how a character is bound to and influenced by certain spaces.

\section{Dramatis Personae}

This term has been chosen deliberately. The dramatis personae, literally the "persons of the play,"15 usually is a list of all the "characters" or the most important "characters" that appear in a dramatic work, and this term can also be used for narrative works. ${ }^{16}$ The "characters" can be arranged in various ways, i.e., alphabetically, according to gender, according to the "characters" status or familial ties, according to their order of appearance, or according to their importance within the drama. ${ }^{17}$ The many "characters" in ActPet can be ordered and categorized accordingly. But just a few observations may help to demonstrate what that might entail.

Peter and Simon Magus play the main roles, which becomes obvious to the reader because of their conflict over religious leadership. While Simon Magus does not appear until ch. 4 , he remains an active character until his end (death?) in ch. 32. Similarly, Peter intervenes only in ch. 5, but thereafter remains the central figure even after his physical death. For example, he appears in Marcellus's dream (ch. 40) and might implicitly be remembered in

14 Consequently, Rome may be the place of origin of ActPet. Cf. Kraus, "Vergegenwärtigende Erinnerung," pp. 139-143 and pp. 149-157. A critical presentation of the arguments for diverse localizations is offered by Döhler, Acta Petri, 43-46, who regards "[d]ie gern bemühte 'mangelnde Ortskenntnis Roms' im Text" (45) as an unconvincing reason to reject Rome as original place of writing. She points out that (46) "vieles ist ohnehin toposhaft, der Text auf Exempla angelegt" and "[e]s werden bekannte Punkte benannt, die nicht unbedingt der Erklärung bedürfen."

15 C. Baldick, The Concise Oxford Dictionary of Literary Terms (Oxford and New York: Oxford University Press, 1990), p. 62.

16 Cf. J. Kühnel, "Dramatis personae," in G. and I. Schweikle (eds.), Metzler Literatur Lexikon: Begriffe und Definitionen (Stuttgart: J.B. Metzler, 2nd edn 199o), p. 111. Since the editing of ancient authors by the Humanists, a list of the (most important) characters is given in printed pieces of drama, but after that the term has also been used for listings in other genres. See, for instance, W. Butler Yeats, Dramatis Personae (London: MacMillan, 1936), who provides a detailed collection of events that influenced his life and people he encountered over the years.

17 Cf. Kühnel, "Dramatis personae," p. 111. 
the final Nero episode (41). A main reason for the late appearance of Simon Magus and Peter is that the Pauline episode (chs. 1-4) provides the background and motivation for the later story: Paul has an epiphany, is recalled, and leaves for Spain. The vacuum of authority after his departure is immediately exploited by Simon Magus for his purposes, who has already been waiting for his chance to come in Aricia. Then, and this occurs by another epiphany, Peter is called into action. The narrative explicitly depicts God speaking directly to Peter, commanding him to set sail for Rome and to confront Simon Magus. The other "characters," however, do not really present the reader with difficulties: it is readily apparent which "character" is important for a single chapter or a closed episode and which one is crucial for the context or the general composition of ActPet.

In the Pauline episode at the very beginning of ActPet, Candida and her husband, the prison guard Quartus, ${ }^{18}$ are part of the prerequisite for the new commission (ch. 1). However, nothing more can be learned about either of them, except that they came to faith through Paul. Such a relation can be used to organize the characters mentioned in ActPet, that is according to specific networks: (a) Paul's network consists of Candida and Quartus, Rufina (ch. 2; on the occasion of a teaching sermon by Paul); Dionysius and Balbus from Asia; Senator Demetrius; Cleobius, Iphitus, Lysimachus, and Aristeus, all four of whom come from the emperor's house; and the noble ladies Berenice and Philostrate (all ch. 3) who are merely mentioned by name. Their attributes serve to define Paul's followers more closely: Christian believers in Rome did not consist (only) of the poor and uneducated, but also consisted of those with a certain amount of wealth as well as social and political influence, and therefore also a certain level of education. Timothy and Barnabas (ch. 4) are also briefly mentioned, but this mention of Timothy and Barnabas could be a means of naming well-known people who might have been possible companions of Paul in Rome. (b) The devil's network includes Simon Magus (cf. the end of ch. 4; ch. 32 "Simon, messenger of the devil"), Herod, Pharaoh, and Caiaphas (ch. 8) being parts of the cursing of Simon Magus, and a nameless youth filled with a demon (ch. 11). Herod, Pharaoh, and Caiaphas, who are obviously historical individuals known to the reader, serve as negative examples spanning a lengthy amount of time, who persecuted the believers (Moses among others). Furthermore, there are Gemellus, Simon's friend (ch. 20), who turns away from Simon Magus, and Marcellus (chs. 8-9), who leaves Simon Magus. (c) Peter's network is made up of Marcellus (ch. 10), the congregational assembly (ch. 4), Theon (ch. 5), Ariston (ch. 6), Narcissus the presbyter (ch. 6), 
a crowd and/or the brothers and sisters (ch. 8 onwards), a nameless youth filled with the Spirit after the demon departs from him (ch. 11), a woman with an infant (ch. 15), Senator Nicostratus's mother and her son (ch. 28), and Chryse (ch. 30). Peter uses the term "sons of Zebedee" (i.e., James and John) in ch. 20 as a reminiscence of the transfiguration of Jesus (Matt 17:1-8; cf. also 2 Peter 1:1628). This, too, might have been known to the rulers or is assumed to have been known. Additionally, Agrippa, a prefect (ch. 28) seems to be against Simon and on Peter's side (ch. 28) first, butchanges sides (ch. 33) after the women Agrippina, Nikaria, Euphemia, and Doris became followers of Peter. Albinus was already on the side against Peter when his wife Xanthippe "came to Peter with the other matrons" (ch. 34). And this opposition to Peter may lead to the formation of another network, i.e., (d) that of Caesar, which provokes the question of whether this network can be related to the devil's network. This issue is mainly addressed within the Martyrdom of Peter (chs. 30-41) and, thus, should be considered seperately in more detail.

A different group of characters is important for a specific chapter or a clearly defined episode. They are active, act and/or narrate, or are embedded into the wider and/or general narrative. In contrast to these characters, Marcellus appears again and again, and he develops as a character. First, he is on the side of the Christian community, then fraternizes with Simon Magus, and finally changes sides again, confesses, follows Peter steadfastly till the very end, and becomes a courageous person who takes high risks (cf. ch. 40: Marcellus, a Roman senator, publicly buries the officially executed Peter). Additionally, the senator is a figure drawn with a rich variety of characteristics (see below).

The following characters are even more interwoven into the narrative representation than the episodic characters: ${ }^{19}$

- Narcissus, a presbyter (chs. 3, 6, 13), remains steadfast and faithful to the faith in Jesus Christ. He is the contact point for Peter after his arrival.

- Agrippa, the prefect, is an active "character" from ch. 24 onwards. He is important and decisive for the execution of the competition (chs. 25-28), appears level-headed and fair, and then becomes a central character, since the plot turns to him and his living together with his "wives" according to the Greek tradition or "concubines" in the Latin version of Pseudo-Linus, where they only appear by name in a list (ch. 33: Agrippina, Icaria, Euphemia, and Doris). He becomes indignant about the sudden sexual abstinence of his wives, as does Albinus, a friend of the emperor, who becomes disgusted by

19 Cf. Lang, Die Taten des Petrus, p. 9, with Agrippa, Marcellus, Narcissus, Paul, Peter, and Simon Magus as "die wichtigsten Personen in den Taten des Petrus" ("the most important people in Acts of Peter"). 
his wife Xantippe's behavior and her refusal of sex (ch. 34). ${ }^{20}$ Furthermore, Xantippe even warns Peter about the prefect's plans of persecution (ch. 35) so that Peter leaves Rome at the advice of his confidants and experiences the famous so-called Quo vadis scene (ch. 35).

- Marcellus, a Roman senator, appears frequently as an active "character" (chs. 8, 9, 10, 11, 14, 19, 22, and 40). On him see below.

Just as the overview of "characters" in ActPet illustrates, Marcellus is one of the named characters in the narratives, and is introduced rather early (ch. 8) after Paul's departure (ch. 4), Peter's arrival (chs. 5-6), and the latter's first inspiring and encouraging theological sermon (ch. 7). Furthermore, he is active and present as a fickle but then repentant and remorseful follower of the Christ faith at the beginning of the intense rivalry between Peter and Simon Magus (chs. 9-11). Thereafter he is clearly a committed companion of Peter see chs. 19 and 22). He is even there in the second main part of the narration, the so-called Martyrdom of Peter (MartPet), in which Marcellus is concerned with the burial of Peter, who appeared to him after death in a dream vision (ch. 40). Thus, Marcellus is a prominent and constant "character" in ActPet who seems to be a prime candidate for a closer analysis by the application of the methodological approach called "cognitive narratology."

\section{The Terms "Character," "Figure," and the Approach of "Cognitive Narratology"}

Up to now the term "character" has been used with quotation marks to indicate that it needs to be defined. In German, the term "Figur" is used as an equivalent to the English term "character," whereas the word "figure" in English covers a broader range of meanings and applications. ${ }^{21}$ In general, a "Figur" may be understood as a "(secondary) person in a literary work (in drama also

20 On asceticism and the chastity of women in early Christianity, especially in the apocryphal Acts of the Apostles, see, for instance, V. Burrus, "Chastity as Autonomy: Women in the Stories of the Apocryphal Acts," Semeia 38 (1986), pp. 101-117; E.A. Clark, "Ascetic Renunciation and Feminine Advancement: A Paradox of Late Ancient Christianity," in eadem, Ascetic Piety and Women's Faith: Essays in Late Ancient Christianity (Studies in Women and Religion 20; New York: Edwin Mellen Press, 1986), pp. 175-208; E.A. Castelli, "Virginity and Its Meaning for Women's Sexuality in Early Christianity," JFSR 2 (1986), pp. 61-88; V. Burrus, Chastity as Autonomy: Women in the Stories of the Apocryphal Acts (Studies in Women and Religion 23; Lewiston: Edwin Mellen Press, 1987).

21 For instance, see the many entries and definitions in the Free Dictionary (https://www. thefreedictionary.com/figure; last accessed 12/10/2020). 
denominated as figurant)."22 However, such a shallow definition does not help to deduce a certain way of "characterizing" or simply analyzing a "Figur." The same would be true of Uri Margolin's short definition: ${ }^{23}$

In the widest sense, "character" designates any entity, individual or collective - normally human or human-like - introduced in a work of narrative fiction.

But Margolin proceeds in outlining a "character" as follows: ${ }^{24}$

Characters thus exist within storyworlds, and play a role, no matter how minor, in one or more of the states of affairs or events told about in the narrative. Character can be succinctly defined as storyworld participant. Now, for its part, the storyworld itself divides into the spheres of narration and of the narrated, the telling and what is told about.

Margolin adds that a "character" is to be embedded in a "storyworld" and evidently is an active part of it (see "play a role" and "participant"). Moreover, he continues by pointing at "proper names," "definite descriptions," and "personal pronouns" as "kinds of referring expressions." Here and there the descriptive definition of a "character" includes that it "is a construct that is developed during the reading process" or, in other words, "an effect of reading." ${ }^{25}$ Although the direct influence of a reader on the understanding of a text and his or her crucial significance for analysis and interpretation has been acknowledged repeatedly and naturally, ${ }^{26}$ a refined systematic and criteria-oriented approach

22 My translation of G. Schweikle, "Figur," in Schweikle and Schweikle, Metzler Literatur Lexikon, p. 156 ("[Neben]Gestalt in einem literar. Werk [im Drama auch Figurant bez.]").

23 U. Margolin, "Character," in D. Herman (ed.), The Cambridge Companion to Narrative (Cambridge: Cambridge University Press, 2007), pp. 66-79, here p. 66.

24 Margolin, "Character," p. 66. Also see U. Margolin, "The Doer and the Deed: Action as a Basis for Characterization in Narrative," Poetics Today 7 (1986), pp. 205-225; idem, "Characters in Literary Narrative: Representation and Signification," Semiotica 106 (1995), pp. 373-392. See further F. Jannidis, "Character," in P. Hühn et al. (eds.), The Living Handbook of Narratology (Hamburg: Hamburg University, http://www.lhn.uni-hamburg.de [last accessed 15/10/2020, contribution revised September 14, 2013]).

25 Burnett, "Characterization," pp. 3-28, here p. 5. Similarly, Uri Margolin in his publications referred to in $n .25$.

26 See, for instance, R. Zimmermann, "Unreliable Figures or Unreliable Narration?" in S.A. Hunt, F. Tolmie, and R. Zimmermann (eds.), Character Studies in the Fourth Gospel: Narrative Approaches to Seventy Figures in John (wUNT 314; Tübingen: Mohr Siebeck, 2013), pp. 71109; idem, "Figurenanalyse im Johannesevangelium: Ein Beitrag zu Sinn und Wahrheit 
has only recently been performed and developed in detail. ${ }^{27}$ This approach appears promising for allowing more in-depth and honest insight into a "character" and the possible or potential effect it might have had at one time and now has on a reader (or a group of readers) and a reader's active part of constructing and reconstructing a "character." 28

According to Jan Rüggemeier this approach seeks to move away from a too exclusive focus on the text and how the story is told and towards a cognitive narratology within which active, constructive, and realistically assessed reader participation is given adequate consideration. In other words, character analysis cannot be reduced to the mentioned traits of a character alone. The comprehensive mental model of a character is derived from textual information, the reading process, and pieces of prior knowledge held by recipients. But this does not mean that the interpretation of an individual reader is automatically independent and even autonomous. ${ }^{29} \mathrm{~A}$ reader now and then (cf. Lucian, Demon 67; Rhet.Her. 1.9.14) is intertwined in their own world so that factors and mechanisms at work must be historically reconstructed. ${ }^{30}$ Consequently, for Rüggemeier a "Figur" (i.e., a "character") is an entity within a narrative and recipients attribute to it the possibility of intentional conduct. ${ }^{31}$ Not only does

narratologischer Exegese," ZNW 105 (2014), pp. 20-53. Also see V. Niederhofer, Konversion in den Paulus- und Theklaakten: Eine narrative Form der Paulusrezeption (WUnT 2/459; Tübingen: Mohr Siebeck, 2017), who, among others, relies on Zimmermann's approach (pp. 15-19).

27 Cf. the comprehensive and critical discussion of narratology in literary criticism and biblical exegesis by Sönke Finnern (Narratologie und biblische Exegese: Eine integrative Methode der Erzählanalyse und ihr Ertrag am Beispiel von Matthäus 28 [WUnT 2/285; Tübingen: Mohr Siebeck, 2010], pp. 23-246), who develops his own approach throughout his survey. Further see the approach by Cornelis Bennema developed and applied in idem, A Theory of Character in New Testament Narrative (Minneapolis: Fortress, 2014); idem, "Character Reconstruction in the New Testament (1): The Theory," ExpTim 127 (2016), pp. 365-374; idem, "Character Reconstruction in the New Testament (2): The Practice," ExpTim 127 (2016), pp. 417-429.

28 See Finnern, Narratologie, pp. 125-163; idem und J. Rüggemeier, Methoden der neutestamentlichen Exegese: Ein Lehr- und Arbeitsbuch (чтв 4212; Tübingen: Narr Francke Attempto, 2016), pp. 173-235; J. Rüggemeier, Poetik der markinischen Christologie: Eine kognitiv-narratologische Exegese (wUNT 2/458; Tübingen: Mohr Siebeck, 2017), pp. 49-77.

29 Cf. Bennema, "Character Reconstruction (2)," 365-366, who advocates for "a particular method" and "a uniform approach to character reconstruction" so that "the comparison of characters both within and across narratives" becomes possible.

30 Cf. Rüggemeier, Poetik, pp. 7-25, especially pp. 9-11.

31 Rüggemeier, Poetik, 52-53 ("Als Figur lassen sich vielmehr alle Entitäten einer Erzählung begreifen, denen die Rezipienten die Möglichkeit intentionalen Handelns zuschreiben können."). Further, see F. Jannidis, Figur und Poetik: Beitrag zu einer historischen Narratologie (Narratologie 3; Berlin and New York: De Gruyter, 2004), p. 120; J. Eder, Figur im Film: Grundlagen der Figurenanalyse (Marburg: Schueren, 2008), pp. 63-64. 
the integration of an active reader imply that a "character" cannot be reduced to only what is actually told and shown in the course of a narration, a "character" is to be understood as a "mental model" 32 and to be seen as entities embedded in a "political, topographical, architectural, temporal, and sociocultural space." ${ }^{33}$ As a result, Jan Rüggemeier lists eleven items as "character features" ("Figurenmerkmale"), ${ }^{34}$ which he refined on the basis of the items in the published abridged version of Sönke Finnern's doctoral thesis ${ }^{35}$ and a method book he and Finnern co-authored. ${ }^{36}$ These items are as follows: (1) character (in the sense of disposition and nature of a character), (2) standpoint (values, norms, and opinions), (3) perception, (4) feelings, (5) behavior, (6) external attributes, (7) space and social-cultural environment (see above), (8) knowledge, (9) duties, (10) wishes/desires, and (11) motivation. ${ }^{37}$ The approach of "cognitive narratology" - as presented here or in slight variation - has already been applied to a number of the texts of the New Testament. ${ }^{38}$

The complex concept of "identity" might represent a particular item on a more abstract level than the eleven terms listed above. That is why Rüggemeier deals with "identity" and conceives it as an "overall mental model" ("das mentale Gesamtmodell") of a character with which recipients can identify and grasp a character's distinctiveness or self-identity. ${ }^{39}$ Consequently, "identity" and even more the "concept of a character," i.e., the assemblage of character

$3^{2}$ Finnern, Narratologie, pp. 38 and 49 and passim; idem and Rüggemeier, Methoden, pp. $195^{-196 .}$

33 Rüggemeier, Poetik, p. 55 ("in einen politischen, topografischen, architektonischen, zeitlichen und soziokulturellen Raum"), who further differentiates the expressions "social context" ("sozialer Kontext"; Finnern, Narratologie, pp. 134 and 138), and "sociocultural environment" ("soziokulturelles Umfeld"; Finnern and Rüggemeier, Methoden, pp. 198 and 200). Implicitly this is discussed in more detail by Finnern, Narratologie, pp. 78-86, though he does not integrate the conclusions he draws from that discussion into his list of items (see the comments by Rüggemeier, Poetik, p. 55 n. 172).

34 Rüggemeier, Poetik, pp. 55-67.

35 Cf. Finnern, Narratologie, pp. 133-143.

36 Cf. Finnern and Rüggemeier, Methoden, pp. 198-202.

37 Rüggemeier, Poetik, p. 55 (“Charakter," "Standpunkt," “Wahrnehmung," "Gefühle," “Verhalten," "Äußeres," "Raum," "Wissen," "Pflichten," “Wünsche," "Motivation”).

38 See Finnern, Narratologie, pp. 247-488 (Matt. 28:1-20); Bennema, A Theory, pp. 114-182 (Mark, John, and Acts of the Apostles); Bennema, "Character Reconstruction (2)," pp. 418428 (Jesus's mother in the canonical gospels); Finnern and Rüggemeier, Methoden, 207-208 (John 20:24-29; performed and written by Simon Blatz); Rüggemeier, Poetik, pp. 199-516 (analysis of the christology in Mark).

39 According to Rüggemeier, Poetik, p. 69 ("Dieses mentale Modell basiert auf zahlreichen Inferenz- und Rekurrenzprozessen, die es dem Rezipienten ermöglichen, eine Figur über den Erzählverlauf hinweg wiederzuerkennen [Reidentifikation] und deren individuelle 
features delineated above which form an "overall mental model," will be in the focus at the very end of an analysis. Of course, the explanation of the method of "cognitive narratology" so far proves that a plain distinction between a "flat" and a "round character" is no longer sufficient, though the creator of the terms, Edward Morgan Forster, never intended them to be dichotomous poles and instead conceived of a greyish zone that exists between them. ${ }^{40}$

Almost needless to say but never to be forgotten, everything that will be discovered and claimed about the character Marcellus in ActPet will be deduced from a reading of the text itself. ${ }^{41}$ Thus, the Marcellus of ActPet would not exist for us without the text of ActPet, ${ }^{42}$ and the author of exactly that text created him. ${ }^{43}$ Today we can do historical research rather easily to obtain additional, extra-textual data to uncover additional information about Marcellus; and

Distinkheit bzw. Selbigkeit [lat.: idem] zu erfassen."). Further see Rüggemeier, Poetik, pp. $54-55$ and $69-71$.

40 See E.M. Forster, Aspects of the Novel (New York: Harcourt \& Brace, 1927), pp. 103-118 and 194, who is not to be blamed for an uncritical and categorizing use of the terms. See Burnett, "Characterization," pp. 18-19. Further see Rüggemeier, Poetik, 72, who refers to Finnern, Narratologie, pp. 156-164, for a more refined distinction of analysis categories (“Veränderung," “Detailliertheit," "Dimensionalität," “Konventionalität," “Transparenz," "Realismus," "Kohärenz," and "Applikabilität") in order to avoid the potential mixture of such categories by the use of "flat" and "round" only. Finnern and Rüggemeier, Methoden, pp. 203-204, also refer to Forster but only list five categories ("Kohärenz," "Dynamik," Dimensionalität," "Konventionalität," and "Transparenz"). Also see Bennema, "Character Reconstruction (1)," p. 366 ("When it comes to New Testament narrative, the majority of scholars regard most characters as 'flat' or 'types.' Even though a number of scholars have come to see greater complexity in the New Testament characters, much of the stereotypical thinking remains.").

41 Cf. Finnern and Rüggemeier, Methoden, p. 204: "Beachten Sie: Die hier vorgestellte Analyse der Figurenkonzeption setzt eine eingehende Beschäftigung mit dem Gesamttext voraus. Auf der Grundlage einer einzelnen Episode ist zumeist noch nicht zu beurteilen, ob sich ein Figurenmodell als kohärent, dynamisch, mehrdimensional usw. erweist." ("Note: The analysis of the 'character' concept presented here requires a thorough study of the entire text. On the basis of a single episode, it is usually not possible to judge whether a 'character' model proves to be coherent, dynamic, multidimensional, etc.")

42 Cf. Margolin, "Character," p. 67: "Texts are necessary for characters to exist and subsist; individual minds are needed to actualize them; and the end result is a relatively stable and enduring inter-subjective entity which can be the subject of legitimate public argument about its properties, for example, Quixote as mad, naïve, an idealist, etc."

43 Cf. Margolin, "Character," p. 67: "Don Quixote did not exist before Cervantes invented him; he is precisely the way his author presents him, and could easily have been otherwise. He was born when the text bearing his name was written down, and will go on living as long as at least one copy of it remains and at least one person reads it." In the course of his reflections Uri Margolin implies that even memory could guarantee the continued existence of a "character." 
this is something early listeners to or readers of the story could not have done. However, the name "Marcellus" is not an identifiable name among senators (and consuls) of Rome,${ }^{44}$ such that historical investigations cannot confirm his existence. Nevertheless, the choice of that name might have prompted early listeners and readers to have confidence in the historical reliability of the narrative.

Be that as it may, in the following the role of the reader will supersede that of the text and the author, even though the text and author guarantee the possibility of an analysis of Marcellus as a character within the textual web of ActPet. Since readers's previous knowledge and, thus, their reading process of ActPet play an influential role in assessing the characterization of Marcellus, the depiction will follow the linear story line and, thus, will map the relevant details about Marcellus and set them against the background of their context. In the process of this analysis, the individual pieces of information will be marked with the numbers (1) to (11), which are also used for the individual character features.

\section{The "Character" Marcellus in ActPet}

For clarity, the central items are given here again with some further explanations about a recipient's role (mentally, "by a recipient" should be added to each item): 45

$\rightarrow(1)$ character (specific features to be ascribed to the character)

$\rightarrow(2)$ standpoint (values, norms, and opinions to be assumed for the character)

$\rightarrow(3)$ perception (sensory perception attributed to the character)

$\rightarrow(4)$ feelings (feelings to be ascribed to the character)

$\rightarrow(5)$ behavior (behavior to be deduced from and expectations to be fulfilled by the character)

$\rightarrow(6)$ outer appearance (outer appearance to be ascribed to the character)

$\rightarrow(7)$ space (spatial, temporal, religious, and sociocultural surroundings)

$\rightarrow(8)$ knowledge (knowledge to be presupposed in the character)

$\rightarrow(9)$ duties (personal or social duties to be assumed for the character)

44 Cf. G. Barbieri, L'albo senatorio da Settimio Severo a Carino, 193-285 (Rome: A. Signorelli, 1952); D. Okoń, Album senatorum, Vols. I-II (Rozprawy I Studia 970 and 993; Szczecin: Wydawnictwo Naukowe Uniwersytetu Szczecińskiego, 2017 and 2018). None of the individuals named "Marcellus" in lists with senators and consuls (cf. the several M. Claudius Marcellus) meets the requirements necessary to fit the character "Marcellus" in ActPet.

45 Sequence and explanatory details according to Rüggemeier, Poetik, p. 55, who includes the "recipient" for each item, whereas in Finnern and Rüggemeier, Methoden, p. 198, the authors form questions in the passive voice without referring explicitly to the "recipient" as agent. 
$\rightarrow(10)$ wishes (fundamental wishes to be assumed with the character)

$\rightarrow(11)$ motivation (motivation to be inferred from a special deed or from specific action)

The following will be far from a complete and methodically consistent analysis. Within the context of an article, I can only present an overall and incomplete analysis of Marcellus as a character, but I will indicate the direction a more comprehensive journey might travel.

\section{Chapters 1-7}

Paul preaches to the fratres - which might be understood as "brothers and sisters," ${ }^{46}$ not only because of the explicit mention of women as integral parts of the crowd (added by the reader) - about steadfastness and strong faith in the Lord (2.16-27) ${ }^{47}$ Already here the crowd clearly expresses doubt and uncertainty by comparing themselves with "children without a mother" (1.13) or react to Paul's sermon with self-doubt: "for we know our infirmity, which is still in us" (Scimus enim nostram infirmitatem, quae est in nobis usque adhuc; 2.27). Simon Magus easily seduces the entire Christian community with only a few exceptions (ch. 4$)^{48}$ and takes over in Rome. Peter is sent there and a few incidents are told along the way (chs. $5^{-6}$ ), before he preaches to the Romans for the first time and exhorts his audience to conversion and firm faith (ch. 7).

46 The English text is cited according to Stoops, The Acts of Peter, and the Latin according to Döhler, Acta Petri. In addition, the following translations are consulted: J.K. Elliott, The Apocryphal New Testament: A Collection of Apocryphal Christian Literature in an English Translation Based on M.R. James (Oxford: Clarendon Press, 1993 [repr. 20o9]), pp. 390-426; W. Schneemelcher, "Petrusakten," in NTApo 6th edn II, pp. 243-258; Lang, Die Taten des Petrus; G. Poupon, "Actes de Pierre," in F. Bovon and P. Geoltrain (eds.), Écrits apocryphes chrétiens I (Paris: Gallimard, 1997), pp. 1041-1114. While Stoops translates as "brothers and sisters," the other translations have "brothers," "Brüder," or "frères."

47 Passage numbering follows the standard style of R.A. Lipsius, "actus Petri cum Simone," in: idem and M. Bonnet (eds.), Acta Apostolorum Apocrypha: 2 vols. in 3 (Leipzig: Mendelssohn, 1891-1903 [repr.: Darmstadt: Wissenschaftliche Buchgesellschaft, 1959]), 1:45-103. In order to refer directly to verses within passages, the system of numeration has been taken over from Stoops, The Acts of Peter.

48 " $[. .$.$] except Narcissus, the presbyter, two women in the Bithynian hospice, and four who$ were no longer able to leave their homes." These pray to the Lord to bring back Paul or "someone else who could visit his servants [...]." Interestingly, at the end of the chapter it is the devil that is blamed for the failure of the Christian community (4.18). 


\section{Chapter 8 (Indicating Individual Items $\rightarrow(x)$ ):}

Consequently, the "brothers and sisters" (fratres) repent and want Peter "to overcome Simon" (8.1). The reader is told that Simon is staying in the house of Marcellus (for that sort of "boundary crossing," see below at "Chapter 9"), "a senator" $(\rightarrow[7,9])^{49}$ who has been "persuaded by Simon's spells" (8.2). Then "the brothers and sisters" report what has happened so far and provide the reader with information about Marcellus (8.3-14): they praise Marcellus's outstanding wisdom (nemo fuit tam sapientoris inter homines, quam hic Marcellus $\rightarrow[r]$, but possibly also 2,3 , and/or 6 ), ${ }^{50}$ outline his works of mercy (refuge for widows, food for orphans, house open for foreigners and the poor; $\rightarrow[5]$ and [2], possibly [4]), and even claim that "all of the poor called Marcellus their patron" (Marcellus omnes pauperi patronum uocabant; $8.4 ; \rightarrow[2]$ and [5], possibly [9]). ${ }^{51}$ His behavior prompts the emperor (imperator and Caesar) to doubt Marcellus's loyalty so that he "holds him back from every office" in the provinces because he fears that the senator would "exploit the provinces and give to the Christians" ( $8.5 ; \rightarrow[5]$, [9], and [2]). The emperor is not convinced by Marcellus's response to this concern ("All my possessions are yours" in 8.6; $\rightarrow[9]$ and [2]) and repeats his doubts (8.7). The next paragraph of the fratres' account deals with Marcellus's total corruption of his attitude and behavior $(8.8-14 ; \rightarrow[5]$ and $[2])$, and the fratres even use Marcellus as an excuse for their own behavior, claiming that if Simon Magus had not seduced and converted him, they "would not have been removed from the holy faith in God, our Lord." This demonstrates how important Marcellus was for the Christians in Rome, although this must be read within the context of the theme of self-excuse or self-justification $(8.9 ; \rightarrow[5]$, maybe $[3]$ if referred to the fratres and the reader as recipients). All in all, the fratres focus on the "money" that Marcellus is said to have spent on people in need, "money" he lost through his generosity and which he regrets having given away. To make things worse in their depiction of Marcellus, they even claim that he expelled people in need by force from his

49 Cf. Döhler, Acta Petri, p. 224, on the common and very popular name "Marcellus."

50 This depends on the interpretation of sapientior. See the reflections on this by Döhler, Acta Petri, pp. 224-225.

$51 \quad$ The attribution to (9) duties depends on an appropriate understanding of "patron" in ActPet. The original Roman idea of legal patronage might be present here and the overall patronage of Christians with a preference for material support (to creating thankfulness and followers). Cf. the discussion in Döhler, Acta Petri, 226-227, who refers to Robert F. Stoops, "Patronage in the Acts of Peter," Semeia 38 (1986), pp. 91-10o, here p. 95, and idem, "Christ as Patron," Semeia 56 (1992), pp. 143-157, here p. 154. 
house $(\rightarrow[5],[9]$, and $[2])$. They end their report with a request: "if the Lord's mercy and the goodness of his commands persist," he should correct Marcellus (8.14). In other words, if the Roman senator finds mercy, they too might find mercy, since they also had been drawn into this miserable situation: losing their faith and following Simon Magus because of their leading authority's failure (cf. 8.9 and 8.5 [Marcellus as patron]; $\rightarrow[$ io] and [5]).52

\section{Chapter 9 (Indicating Individual Items $\rightarrow[x]$ ):}

Although the scene takes place in Marcellus's house, the senator himself does not play an active role in it. Nevertheless, the presence of Simon Magus marks a crossing of boundaries between spaces that can be called "restitutive," because the magician and his followers will not stay in the house for long. ${ }^{53}$ After Peter's sermon on the temptations and threats of the devil $\left(8.15^{-} 32\right),{ }^{54}$ the group of believers increases again (9.1) and the "brothers and sisters" (fratres) ask Peter "to confront Simon so he would not be free to disturb the people any longer" (9.2). At once Peter, accompanied by "large crowds" (which becomes customary from this point on in the narrative), walks over to Marcellus's house. ${ }^{55}$ At the door, Peter (together with the crowd) is received by an ostiarius (9.5), either just a "doorkeeper" or a person holding a low ecclesiastical office (someone who has received the first four orders). The latter may be the preferred meaning due to the fact that (a) ActPet denotes other ecclesiastical offices by name (deacon, episcope, and presbyter) and (b) Marcellus's house has already been a meeting place for Christians $(\rightarrow[7]) \cdot{ }^{56}$ It seems as if Simon Magus and his followers reside in the senator's house in whatever capacity they see fit $(\rightarrow[7])$. Even when the talking dog is sent inside by Peter to challenge Simon Magus, Marcellus remains passive at first: he does not interfere nor does he immediately appear at the door $(\rightarrow[5],[7]$ and $[1])$.

$5^{2}$ According to Döhler, Acta Petri, p. 227.

53 According to Martínez and Scheffel, Einführung in die Erzähltheorie, pp. 163-164.

54 See the philological and theological notes provided by Döhler, Acta Petri, pp. 227-231.

55 Interestingly, the Latin has synagoga for the gathering Peter leaves. Here the general term "assembly" may fit best and not a religious equivalent. For a discussion, see Döhler, Acta Petri, pp. 231-233.

$5^{6}$ For details and bibliographical references, see Döhler, Acta Petri, p. 233. 


\section{Chapter 10 (Indicating Individual Items $\rightarrow[x]$ ):}

But after the miraculous appearance of the dog and Simon's reaction to it (10.1), Marcellus comes to the door, falls down at and embraces Peter's feet, and delivers a rhetorically effective and affectively moving speech (sancte dei sancti seruus "Holy servant of the holy God"; sanctus seruus in ch. 8 for Moses and in ch. 22 for Peter) in 10.2-18. Marcellus expresses his hope that he will not be punished ("eternal fire"), confesses his sins, and begs Peter to pray for him before the Lord $(\rightarrow[\boldsymbol{r o}])$. His main topics are repentance and remorse, mercy and forgiveness. Although Marcellus refers to Simon Magus's seducing force and says that Simon Magus claimed to be "the Power of God," what may be felt as a slight attempt to excuse his actions, he leaves no doubt about his own responsibility for his failure $(\rightarrow[2]$ and [5]). The senator even dedicated a statue to Simon Magus (10.6)..$^{57}$ Moreover, by alluding to Peter's doubts when he was "on the water" (which is perhaps an allusion to Matt. 14:28-33; but Jesus' Walking on the Water and Peter's doubts have rather early become an often referred to episode and Peter might have been seen as an already well-known "transworld character") $)^{58}$ and by recalling a narrative about Jesus placing his hands on Peter, Marcellus draws an analogous situation between Peter's own doubts and Marcellus's (10.12-16), ${ }^{59}$ and also demonstrates Marcellus's own knowledge of relevant sections of the New Testament $(\rightarrow[8]$ and, maybe, implicitly [7]). Peter prays to "our Lord [...], omnipotent God, Father of our Lord Jesus Christ" (10.19) for Marcellus, who has confirmed his faith in front of him and the crowd $(\rightarrow[2],[5]$ and $[n])$, to be accepted "as one of your lambs" and to be received "into the number of your sheep," though he "entreat[ed] you with anguish and tears." Thus, Marcellus's wish is fulfilled (10.22-23; $\rightarrow[10])$.

57 The discussion of the inscribed statue and its background is illustrated in Döhler, Acta Petri, pp. 235-236; Zwierlein, Petrus und Paulus, pp. 25-26. Also see Stoops, The Acts of Peter, p. 59 note on 10.6. In a forthcoming study, I will deal with the "statues" (10.6 and ch. 11) in ActPet in greater detail and how they are presented in comparison with the other major Apocryphal Acts of the Apostles and some other relevant Christian texts.

58 See B. Schliesser, "Der Seewandel des Petrus (Mt 14,28-31) in frühchristlicher Literatur und Kunst: Zur Wirkungsgeschichte einer unbequemen Petruserzählung," in Frey and Wallraff, Petrusliteratur und Petrusarchäologie, pp. 43-86, especially pp. 54-78, for the rich and varied reception and impact history of this episode.

59 See the references to passages of the New Testament in Schneemelcher, "Petrusakten," p. 268; Döhler, Acta Petri, pp. 236-238, and, above all, in Stoops, The Acts of Peter, pp. 58-6o (in the outer margins). 


\section{Chapter 11 (Indicating Individual Items $\rightarrow[x]$ ):}

Still situated in Marcellus's house, the next episode is about an exorcism and the destruction and miraculous restitution of a statue of the emperor. ${ }^{60}$ I focus mainly on determining the relevant character features here. First, only Peter is active. After the destruction of the "statue of Caesar" (statua Caesaris; 11.10), Marcellus is alarmed and describes the event as "a great offence" (magnum flagitium). He fears that "Caesar's spies" (de curiosis; $\left.{ }^{61} 11.11\right)$ might report the incident and that he and others would be punished $(\rightarrow[4])$. This implies that the (almost omnipresent) crowd is not a homogenous group of loyal Christians, that Marcellus might be under surveillance to ensure he is loyal in accordance with his status as a senator, and that he knows "spies" are present $(\rightarrow[8]$ and [5], $[9])$. We may also see his strong belief in Roman political power here $(\rightarrow[5])$, but now his changed disposition and complete confidence in Peter and the Lord $(\rightarrow[(11)],[(1)]$ and $[(5)]=$ becomes active himself): Peter confirms that Marcellus has changed and is even more rooted in the faith than when he first began. He is steadfast and willing to give up everything for the "salvation of your soul" and is "trusting in Christ with all your heart" (11.13). Marcellus does as he is told (e.g., he prays and sprinkles water over the fragments of the statue as a sort of ritual). "Marcellus did not hesitate, but trusted with all his heart" (11.15). He praises God, confesses his belief, and asks the Lord Jesus Christ to help him and the statue become whole again (11.16-20). Thus, Marcellus does not have to fear the emperor and/or his spies any longer. ${ }^{62}$ The "remarkable first sign [...] through his hands" is reminiscent of 10.15 when Marcellus referred to the marvels Jesus worked together with Peter $(\rightarrow[8]$ and $[n])$. Marcellus's house obviously is of great significance $(\rightarrow[7])$ for decisive events and for the steadfastness and faith of the Christians in Rome.

6o On ActPet 11, see C. Callon, "Images of Empire, Imaging the Self: The Significance of the Imperial Statue Episode in the Acts of Peter," HTR 106 (2013), pp. 331-355.

61 On curiosi as an official title, see Döhler, Acta Petri, p. 241.

62 Cf. Döhler, Acta Petri, p. 242, who indicates that the restitution miracle has a threefold consequence: (a) Marcellus is restored for the Christian faith and his community. (b) The statue is whole again: (c) With reference to Callon, "Images," p. 347, the restitution of the statue might also have a political dimension as it represents the conflict between being a Christian and being loyal to the emperor. 


\section{Chapter 12-13 (Indicating Individual Items $\rightarrow[x]$ ):}

Marcellus's house remains the central place of action $(\rightarrow[7])$, but Marcellus's presence is just mentioned once (12.2) indicating that he is still witnessing what is going on $(\rightarrow[11])$, i.e., the conversation with the speaking dog and the herring coming to life again (ch. 13). The miracles motivate more and more people to follow Peter and to become faithful.

\section{Chapter 14 (Indicating Individual Items $\rightarrow[x]$ ):}

The narrative depicts Marcellus as becoming gradually stronger (in his faith; 14.1), so much so that he even "attacked Simon in his own house as he sat in the dining room." Obviously, Simon still felt safe and free to do whatever he wanted in Marcellus's house $(\rightarrow[7]$, but also [2]). Although, he laid hands on Simon himself, he gave orders to his slaves to throw the Magician out of the house (14.4). The slaves treat Simon brutally and deeply humiliate him (14.5-9a), so that he runs away to the house of Narcissus, the place where Peter was staying, to challenge the apostle to a duel (14.9b-11). Consequently, after Marcellus's repentance, Peter's intervention, and Simon's expulsion from the house, the senator's home becomes a permanent Christian meeting place. Thus, expelling Simon might be seen as a "revolutionary boundary crossing." ${ }^{63}$ Interestingly, the formerly fickle and easily swayed Marcellus is presented as a strict and violent (14.2-4: impetus ["attack"], maledicens dicebat ei ["he cursed him"], et iniciens manus in eum ["laying hands on him"]) master of his household. He confidently gives orders to his ostiarius and is a slave owner, something that suits his status and position as a senator $(\rightarrow[2],[5]$, and $[1])$.

\section{Chapters 19 and 22 (Indicating Individual Items $\rightarrow(x)$ ):}

After a long pause, these two chapters prove that "Marcellus and the other brothers and sisters" (22.1) are still with Peter. Marcellus even seems close to the apostle and plays a self-initiative role: he reports about "cleansing" his house of the traces of Simon, praying, and sprinkling the rooms with water (19.2-3) to prepare "the communal house" for "the service" (19.5-6). ${ }^{64}$ Consequently, Marcellus applies what he learned, experienced, and utilized

63 Cf. Martínez and Scheffel, Einführung in die Erzähltheorie, pp. 163-164.

64 On the term aspersio, see Döhler, Acta Petri, pp. 256-258. 
during the restitution of the broken statue of the emperor (ch. 11). Peter seems to be satisfied with what Marcellus says and does (19.9). The same impression is conveyed in ch. 22, i.e., Marcellus talks to the "Lord's virgins" or "holy, inviolate virgins of the Lord" (22.2) and leads the action, falls asleep (22.9), and continues the communication, this time with Peter (22.9-18), about a dream vision he received while sleeping. Obviously, Marcellus does not see himself in a position to fight against the demon he saw in his vision, though he could heal the damage done by the demon (i.e., to restore the broken statue), indicating that the senator knew about his limits and about the power of Peter and Jesus Christ $(\rightarrow[5]$ and $[8]) .{ }^{65}$ The stage has now been set for the showdown between Simon Magus and Peter, the brothers and sisters (fratres), as well as Marcellus (implicitly included among the fratres) are present in chs. 23-26.

\section{Chapter $4^{66}$ (Indicating Individual Items $\rightarrow[x]$ ):}

After that Peter, hanging inverted on the cross, ended his long sermon (chs.

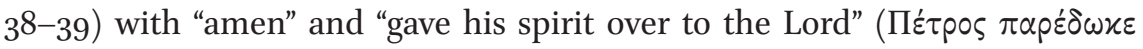

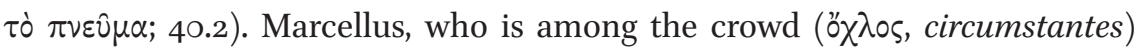
present at the crucifixion, takes the dead body down from the cross "with his

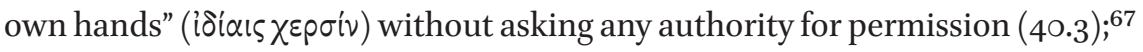
washes it with "milk and wine"; mixes "seven minas of myrrh," "fifty [minas] of aloe," and "other herbs"; embalms Peter's remains ( $\lambda \varepsilon$ qi $\psi \alpha v \circ v)$; lays them into a "sarcophagus with Attic honey"; and places "them in his own tomb" (40.3-5). This episode is reminiscent of Joseph of Arimathea (cf. Matt. 27:57-6o; Mark 15:43-46; Luke 23:50-54; John 19:38-42), but Marcellus takes Peter down from the cross "without receiving authorization from anyone," which is highlighted by the clause "this was not allowed," which immediately follows (cf. Joseph of Arimathea who was granted permission by Pilate). This portrayal of a Roman

65 Cf. Döhler, Acta Petri, p. 272.

66 In addition to Actus Vercellenses, the Greek manuscripts (P, A, and O) are of special importance for MartPet (chs. 30-41) within ActPet. Cf. Zwierlein, Petrus in Rom, pp. 337-40o, especially p. 338; Eastman, The Ancient Martyrdom Accounts, p. 3. For a critical edition of the Greek text (accompanied by a German translation), see Zwierlein, Petrus in Rom, pp. 403-425 (pp. 420-423 with ch. 40).

67 Stoops, The Acts of Peter, p. 92, and Eastman, The Ancient Martyrdom Accounts, p. 23, understand the Greek here as denoting Marcellus's act of taking Peter down from the cross as something illegal ("this was not allowed"). But see Zwierlein, Petrus in Rom, p. 421, understands the clause in a different way ("was ja auch nicht möglich gewesen wäre", i.e., to obtain permission). 
public figure who openly acts against Roman regulations and the emphatic mention of the illegality of his deed is extraordinary. The tension here is even stronger than the confrontation between the senator and the emperor reported by the fratres (8.5-7), thus Marcellus is presented as a courageous believer. In that context the term $\pi \circ \lambda \lambda \circ \hat{\tau} \tau \mu \eta \dot{\mu} \mu \alpha \tau \varsigma^{68}$ is important, because it underlines the financial effort Marcellus makes. ${ }^{69}$ Here Marcellus is presented as a self-conscious and active character $(\rightarrow[5]$ and [2]). He may be viewed as someone who sacrifices everything he owns and even gives up "his own tomb" for Peter as a favor for a dear companion $(\rightarrow[(4)])$. However, Peter's appearance at night proves that Marcellus's behavior is to be criticized, because he should "leave the dead to be buried by their own dead" and "[t]hese things that you have provided for the dead, you have lost" $(40.6-7 ; \rightarrow[4]$ and $[5]) .{ }^{70}$ Marcellus wakes up and tells "the brothers and sisters" (fratres, $\dot{\alpha} \delta \varepsilon \lambda \varphi \varphi^{\circ}$ ) about his encounter with Peter at night and they are "strengthened in faith in Christ by Peter" (40.9). The fact that he himself was also strengthened that way distinguishes him within the narrative and adds emphasis (40.10; $\rightarrow[2]$, [4], and [5], maybe even [ $[1]$ and $[8]$ ); and that fact that Marcellus is distinguished among brothers and sisters should be so "until Paul's arrival in Rome."

As a reader who has enjoyed some theological training and knows the New Testament and some early Christian texts pretty well, it is obvious to me that there is a connection between ActPet 40.6 and Matt. 8:22 // Luke 9:6o. The text itself, in other words the nocturnal communication between Marcellus and Peter, elucidates the meaning of "Leave the dead to be buried by their own dead" in 40.7 (see above) so that my background knowledge might not be necessary for understanding the critical tone underlying the narrative. ${ }^{71}$

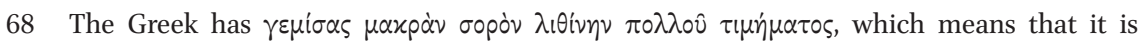
a container or vessel for the remains of a deceased person. As it stands the phrase "Attic

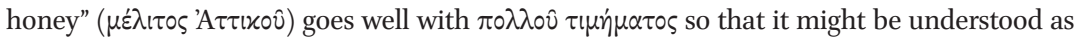
"honey of the greatest value" (Stoops, The Acts of Peter, p. 92; similar Eastman, The Ancient Martyrdom Accounts, p. 23), while Zwierlein, Petrus in Rom, p. 423, translates "sehr kostbaren Steinsarg," thus, referring the genitive of $\tau \dot{0} \tau i \mu \eta \mu \alpha$ to бopòv $\lambda_{\imath} \theta i v \eta \nu$.

69 Cf. Döhler, Acta Petri, p. 314.

70 Marcellus should have given his belongings to the poor instead and not to the dead. Cf. Döhler, Acta Petri, p. 314.

71 See the reflections by Döhler, Acta Petri, p. 314, about the subtle criticism expressed in that section. 


\section{The Active Role of a Reader (or Listener to the Story)}

As indicated above, a reader who has enjoyed theological training with a specialization on the texts of the New Testament and early Christianity can clearly see that ActPet is saturated with allusions to and even direct quotations from the New Testament texts. The major translations provide a wide selection of references in their margins and apparatuses. Nevertheless, the text itself offers explanations of some of these allusions and/or quotations, while others might be understood rather easily without identifying them as such from their embedment in the narrative context. Marcellus, for instance, utilizes Paul's own doubts as a defense for his own weakness. The informed reader or listener - the latter term being used as a reminder of the socio-cultural setting for reading and writing in (late) antiquity - might quickly recall Peter's failures as a whole and in detail (see, above all, Matt. 14:28-32; 26:33-5, 69-75). However, the context in ActPet makes it only necessary to know that Peter was once weak and full of doubts on the water and not much more to allow a parallel between the two characters. All in all, a reader (or listener) receives apt and sufficient pieces of information from the narration, and these pieces of information are always given in time to prepare the reader or listener for the next steps along the story line. Due to space limitations, I cannot add much more here about important factors such as inference processes and reading memory, on recency and primary effects that influence a reader decisively or the role a narrator plays for the narration. ${ }^{72}$ However, Marcellus is still there after Peter's death and sincerely desires to bury the apostle respectfully, adequately, and affectively.

Peter - who stumbled, changed his ways, repented, and then was steadfast in faith - does not leave any doubt about his own failures and his reformation (7.11-15) so that he can point at the model this can represent for the "brothers and sisters" (7.16-27) to encourage them and to bind them strongly to Jesus Christ. And just from reading the text and without any previous knowledge of course, it is (almost) impossible to eliminate one's own education, socialization, and knowledge - I can quickly recognize that Marcellus's way is modelled after Peter's example. Finally, Marcellus can even work miracles (by relying strongly on prayers and ritual actions, i.e., on God and Jesus Christ) and is present with Peter even after his death. Thus, Marcellus becomes what he has always been in ActPet, though to a different extent as a positive or negative role model: he is the decisive character for the Christian community in Rome and the crucial person for the individual success or failure of each of its members.

72 On these see Rüggemeier, Poetik, pp. 14-17. See pp. 32-40 for the role of the narrator. 


\section{Instead of an Analytical Synopsis - Some Concluding Remarks}

Sometimes it was not so easy for me to decide which of the eleven item(s) should be used to categorize a certain observation. Furthermore, an effective analysis would require a synopsis of all the observations and their categorization in greater detail. Moreover, the comparison of characters and their individual features would be an additional step for an effective analysis of a special character such as Marcellus. ${ }^{73}$

Be that as it may, there is not much to say about Marcellus's outer appearance $(\rightarrow[6])$. Marcellus appears as a sensitive and empathic character $(\rightarrow[4])$, who can also be strict and harsh when it comes to giving orders and to standing up against an enemy such as $\operatorname{Simon}(\rightarrow[3]$ and [5] ). At the same time he was seduced by Simon Magus into blasphemous behavior and, thereby, became a passive character $(\rightarrow[5])$. Simultaneously, the values, norms, and opinions he holds, as assumed by me as a recipient, are ambiguous in that respect, as he was a steadfast and reliable believer, was easily persuaded into heresy by Simon, and came back to the true faith by means of miracles performed by Peter and his prayers and deep trust in God and Jesus Christ $(\rightarrow[2]$ and [ $[\boldsymbol{r o}])$. Most interesting to me are the items as follows.

Marcellus's motivation is to be a follower of Jesus Christ or, in other words, of Peter as a representative of the Christian faith. This explains his charity work but also his (omni)presence at the side of Peter put him in danger $(\rightarrow[11])$. Apart from what a senator should know due to his office and status, Marcellus has a significant amount of knowledge $(\rightarrow[8])$ about Christian rituals and texts (e.g., see his references to the New Testament and to the "communal house" and "service) such that he can be called a "Christian." ${ }^{4}$ His house $(\rightarrow[7])$ is of crucial importance (a) for the narrative, (b) for the conflict between Peter and Simon Magus, and (c) for the Roman community and communal life in Rome as a meeting place where ritual gatherings evidently took place. Besides, Marcellus embodies the inner conflict a member of the Roman establishment had to face at that time (cf. his confrontation with the emperor in $8.5^{-7}$ and his courageous and illegal deeds as a public Roman figure for Peter's burial). On the one hand, he supports the poor and desperate, opens his house for Christians, and obviously wants to be a part of that community for which he is of vital importance. On the other hand, Marcellus is a Roman senator with

73 Cf., for instance, Finnern, Narratologie, pp. 144-147.

74 With Döhler, Acta Petri, pp. 224-225, against G. Poupon, 'Les 'Actes de Pierre' et leur remaniement," ANRW 2.25/6 (1988), pp. 4365-4383, here p. 4375, who takes ch. 8 (the term sapientior) as a proof of the fact that Marcellus has not already been a Christian there. 
all the duties - personal, social, or public - a senator has to fulfil. These duties become visible in the narration in several instances: he has slaves in his house, he gives instructions, his political career is mentioned, he has a statue of the emperor in his house as an expression of loyalty, and he has people close to the court of the emperor ("spies") as (unavoidable) guests in his house $(\rightarrow[9])$. Thus, he cannot simply hide away but is a person of public interest. Hence, Marcellus comes into conflict with Christian values, or rather Christian "duties" $(\rightarrow[9])$; he is torn apart between two worlds that cannot be easily reconciled for a person of his status and significance. Either he is loyal to the emperor or to Jesus Christ, either he plays his role as a senator as a part of the Roman establishment or he is a full member of the Christian community who may lose all his financial support and political influence that community may benefit from. Either he acts as a Christian in an absolute, resolute way by dismissing slavery and putting away his idolatry, or lead a double life by keeping his two different "identities" separate from each other.

Interestingly, these two different "identities" cause some tension for Marcellus. His character is developed throughout the narrative. First, he is a central figure of the Christian community in Rome and his house is a meeting place. But then he becomes a fickle person and follows Simon Magus. After the talking dog called Simon out of the house for a challenge, Marcellus repents and confesses his faith. Thereafter he is a steadfast follower of Peter and, thus, Jesus Christ. He is even taught how to perform miracles. Thus, he becomes a more and more active character, who is granted a posthumous appearance from Peter (40.6-7), reports about his encounter to "the brothers and sisters," and is "further strengthened until Paul's arrival in Rome" (40.8-9). Therefore, he develops from a gracious and generous Roman senator to a steadfast believer in Jesus Christ and significant member of the Christian community in Rome.

However, Marcellus does not have to choose between two dichotomous options: the conversation between Marcellus and the emperor, reported by the fratres (8.5-7), and the incident of the broken statue of the emperor illustrate that the senator did not need to abandon anything or to hide his private and social life. Obviously, he could reconcile loyalty to the emperor and Jesus Christ and, thus, be both a representative of the Roman state and a Christian. ${ }^{75}$ And this is what can be said about his "identity."76

Although certain aspects about Marcellus as a character mentioned above are nothing new and can be easily deduced from scanning and skimming the

75 In agreement with Döhler, Acta Petri, p. 242. Also see Callon, "Images of Empire," p. 347.

76 Cf. Rüggemeier, Poetik, pp. 54-55, who, more or less, regards "identity" as a result of or a synopsis of the various character features within the text. 
text as it is and by including the historical background, "cognitive narratology" as it is understood and applied in this study helps to categorize, reflect upon, rearrange, and intertwine the diverse observations readers make during the course of their reading processes. Moreover, some assumptions received additional support (e.g., the house as a central spatial element, Marcellus as a Christian, and the parallels between Peter and Marcellus) with the result that the "character" Marcellus receives more recognizable contours and becomes clearer as a Christian figure of that age as well as for our own. ${ }^{77}$

77 I am deeply indebted to Elizabeth Shively and Jan Rüggemeier for their sensitive and supportive editing and, above all, their insightful and concise suggestions. 